\title{
Comorbidity with depression and overweight in children with asthma
}

\author{
Salma Bahreinian ${ }^{1 *}$, Geoff DC Ball ${ }^{1}$, Allan B Becker ${ }^{2}$, Anita L Kozyrskyj ${ }^{1}$ \\ From Canadian Society of Allergy and Clinical Immunology Annual Scientific Meeting 2010 \\ Victoria, Canada. 3-6 November 2010
}

\section{Background}

In Canada $16.6 \%$ of children are affected by asthma [1] which may increase the risk of comorbid depressive disorders in the adolescent years [2,3]. Overweight is more prevalent in children suffering from asthma [4] or depression [5], yet few studies have explored the possible relationships between these three chronic conditions in children. We examined whether depression was more prevalent in children with asthma, especially among those who were overweight.

\section{Materials and methods}

Data were collected as a part of the nested case-control study of the Study of Asthma, Genes and Environment (SAGE) cohort in Manitoba. All the children enrolled in the study at age 7-10 were reassessed by a pediatric allergist at 11-13 years to confirm asthma/atopy diagnosis. At the same visit, height and weight were obtained. Depressive symptoms were also assessed using the short form of the children's depression inventory (CDI-S). Depression was defined as CDI-S scores $\geq 2$ (highest quartile of population under the study). Overweight was defined as BMI-z score $>1.04$. Data were analyzed using logistic regression modeling to determine likelihood of depression in children with asthma, stratified by sex and adjusting for age, overweight and atopy.

\section{Results}

A total of 485 children at 11-13 years (150 asthmatics and 335 non asthmatics) were enrolled in the study (Table 1). There was no statistically significant difference in overweight between children with versus without asthma $(\mathrm{p}=0.4)$ and we found the prevalence of

\footnotetext{
* Correspondence: bahreini@ualberta.ca

'Dept Pediatrics, Faculty of Medicine \& Dentistry, University of Alberta,

Edmonton, Alberta, Candada,T6G 2J3

Full list of author information is available at the end of the article
}

Table 1 Basic distribution of study variables

\begin{tabular}{lcc}
\hline Variable Name & Positive & Negative \\
\hline Depression & $30 \%$ & $70 \%$ \\
Overweight* $^{*}$ & $31.8 \%$ & $68.2 \%$ \\
Asthma & $30.9 \%$ & $69.1 \%$ \\
Atopy $^{* *}$ & $53.2 \%$ & $46.8 \%$ \\
& Male & Female \\
Gender & $55.9 \%$ & $44.1 \%$ \\
\hline
\end{tabular}

*Overweight: BMI-z score > 1.04 .

**Atopy: positive skin prick test to at least one common allergen.

depression to be similar among those with $(33.8 \%)$ versus without $(28.1 \%)$ asthma $(\mathrm{p}=0.2)$. Overweight was associated with higher odds of depression in girls independent of age and asthma/atopy status (adjusted $\mathrm{OR}=2.1,95 \% \mathrm{CI}=1.02$ to 4.22 ). In addition, asthmatic boys were more likely to experience depression after adjusting for age, overweight and atopy (adjusted $\mathrm{OR}=1.94,95 \% \mathrm{CI}=1.01$ to 3.71 ) (Table 2).

\section{Conclusions}

Overweight appears to be an important predictor of depression in girls regardless of their asthma status. Although asthma status does not increase the likelihood of depression in girls, it appears to increase the odds of depression among boys.

Table 2 Likelihood of depression in children

\begin{tabular}{|c|c|c|c|}
\hline $\begin{array}{l}\text { Adjusted } \\
\mathrm{OR}^{*}(95 \% \mathrm{Cl})\end{array}$ & Overweight & Asthma & Atopy \\
\hline Girls & 2.1 (1.02 to 4.22$)$ & .92 (.46 to 1.84$)$ & 1.07 (.56 to 2.04) \\
\hline Boys & 1.28 (.69 to 2.37$)$ & $1.94(1.01$ to 3.71$)$ & .66 (.36 to 1.24$)$ \\
\hline
\end{tabular}

*Adjusted for overweight, asthma, atopy and age. 


\section{Acknowledgments}

This research was funded by AllerGen NCE Inc and the Canadian Institutes of Health Research: new emerging team and operating grants in origins of asthma. Salma Bahreinian is supported by the Women and Children's Health Research Institute. We would also like to acknowledge the support of the SAGE research team.

\section{Author details}

'Dept Pediatrics, Faculty of Medicine \& Dentistry, University of Alberta, Edmonton, Alberta, Candada,T6G 2J3. ${ }^{2}$ Dept Pediatrics and Child Health, Faculty of Medicine, University of Manitoba, Winnipeg, Manitoba, Canada, R3A 1S1

\section{Published: 4 November 2010}

\section{References}

1. Public health agency of Canada: Life and breath: respiratory disease in Canada, 2007. Ottawa: public health agency of Canada41, Cat.: HP35-8/ 2007E-PDF.

2. Ortega AN, Huertas SE, Canino G, Ramirez R, Rubio-Stipec M: Childhood asthma, chronic illness, and psychiatric disorders. J Nerv Ment Dis 2002, 190:275-81

3. McQuaid EL, Kopel SJ, Nassau JH: Behavioral adjustment in children with asthma: a meta-analysis. J Dev Behav Pediatr 2001, 22:430-9.

4. Vahlkvist S, Pedersen S: Fitness, daily activity and body composition in children with newly diagnosed, untreated asthma. Allergy 2009, 64:1649-1655.

5. Anderson SE, Cohen P, Naumova EN, Jacques PF, Must A: Adolescent obesity and risk for subsequent major depressive disorder and anxiety disorder: prospective evidence. Psychosom Med 2007, 69:740-747.

doi:10.1186/1710-1492-6-S2-P10

Cite this article as: Bahreinian et al: Comorbidity with depression and overweight in children with asthma. Allergy, Asthma \& Clinical Immunology 2010 6(Suppl 2):P10.

\section{Submit your next manuscript to BioMed Central and take full advantage of:}

- Convenient online submission

- Thorough peer review

- No space constraints or color figure charges

- Immediate publication on acceptance

- Inclusion in PubMed, CAS, Scopus and Google Scholar

- Research which is freely available for redistribution

Submit your manuscript at www.biomedcentral.com/submit 